\title{
Digitized Education: \\ A New Social Divide between Rural and Urban India
}

\author{
Dr. Anitha Jagathkar (Ph.D.), \\ Director, Education Interventions, Saburi Education Solutions
}

\begin{abstract}
Digital learning is any instructional practice that effectively uses technology to strengthen a student's learning experience. It entails high-quality instruction, at the same time allows students to access content through presentations and assessments. Feedback is also one of the elements, akin to classroom teaching. Digital learning's prime benefit is that it offers opportunities to innumerable learners to learn anytime and anywhere. Yes, individualized instruction is possible through online learning as the learner can attend classes based on his readiness and interest and reach his full potential.
\end{abstract}

Key words: Digital Education, Education, Digital India

\section{Introduction}

Digital learning is any instructional practice that effectively uses technology to strengthen a student's learning experience. It entails high-quality instruction, at the same time allows students to access content through presentations and assessments. Feedback is also one of the elements, akin to classroom teaching. Digital learning's prime benefit is that it offers opportunities to innumerable learners to learn anytime and anywhere. Yes, individualized instruction is possible through online learning as the learner can attend classes based on his readiness and interest and reach his full potential.

The design of Digital learning is not as simple as it seems. It uses different platforms, tools, software and applications to support and empower teachers and students. In addition to the equipment, it uses course material, resources and other support structures. The scope of digital learning is vast and wide. It does not limit itself to educate students in schools but spreads across genres and courses to teach professionals and teachers.

It expands learning opportunities, giving students to research areas of interest. Since digital learning would be a personal experience, it would make students more responsible and accountable for their own learning. Online learning with only a screen between teachers and students would pave way for competence-based learning as learners would learn and assimilate content based on their own capacities, talents and capabilities.

Given the current situation, online learning is the best available option for learners across the world. It would be one of the major reforms in the field of education as it ensures learning opportunities for several learners at a fingertip even in testing, turbulent times. While, in the long run, it may enhance teaching experience for learners in distant areas, enhancing teaching competence may still not be an outcome as teaching online is totally different from teaching traditionally in a classroom.

But is India ready for digital learning? If we look at various statistics, we understand that we still lack the basic infrastructure and the technical knowhow to switch to online teaching abruptly and suddenly just because of unforeseen situation and circumstances. Transition from age-old traditions to novel ways requires strategic planning, budget and a detailed review and research-based evidence of readiness and acceptance. Therefore, digital learning is not the permanent solution although it can offer solace to the stakeholders' community that the learning continuum is maintained.

\section{Digital Power of India}

\begin{tabular}{|l|l|}
\hline Source & Statistics \\
\hline $\begin{array}{l}\text { Global survey } \\
\text { report by a private } \\
\text { agency }\end{array}$ & $\begin{array}{l}\text { - One in four Indians own a smart } \\
\text { phone }\end{array}$ \\
\hline $\begin{array}{l}\text { National Sample } \\
\text { Survey report on } \\
\text { education 2017-18 }\end{array}$ & $\begin{array}{l}\text { - Only 24\% of Indian households } \\
\text { have an internet facility }\end{array}$ \\
& $\begin{array}{l}\text { - Over 15\% rural households have } \\
\text { access to internet services }\end{array}$ \\
\hline $\begin{array}{l}\text { National sample } \\
\text { survey definition }\end{array}$ & $\begin{array}{l}\text { Only 8\% of all households with } \\
\text { members aged between five and } \\
\text { 24 have both a computer and an } \\
\text { internet connection. }\end{array}$ \\
\hline
\end{tabular}




\begin{tabular}{|c|c|}
\hline Source & Statistics \\
\hline $\begin{array}{l}\text { National statistical } \\
\text { office report 2017- } \\
18\end{array}$ & $\begin{array}{l}\text { - } 4.6 \% \text { access computer in Bihar } \\
\text { - } 23.5 \% \text { in Kerala and } 35 \% \text { in } \\
\text { Delhi. } \\
\text { - } \text { More than } 40 \% \text { households have } \\
\text { access to internet in Delhi, Kerala, } \\
\text { Himachal Pradesh, Haryana etc. } \\
\text { - Less than } 20 \% \text { have access to } \\
\text { internet in Odisha, Andhra } \\
\text { Pradesh, Assam, Bihar, } \\
\text { Chhattisgarh, Jharkhand, Madhya } \\
\text { Pradesh and West Bengal. }\end{array}$ \\
\hline $\begin{array}{l}\text { Internet and } \\
\text { Mobile } \\
\text { Association of } \\
\text { India } 2019 \text { report }\end{array}$ & $\begin{array}{l}\text { - } 67 \% \text { men had access to internet } \\
\text { - } 33 \% \text { women only had access to } \\
\text { internet }\end{array}$ \\
\hline $\begin{array}{l}\text { HRD ministry } \\
\text { report }\end{array}$ & $\begin{array}{l}\text { - digital e-learning budget reduced } \\
\text { to Rs } 469 \text { crore from Rs } 604 \text { crore } \\
\text { in } 2019-20 \text {. }\end{array}$ \\
\hline
\end{tabular}

\section{Principles of Learning- Outside Classroom}

There are certain principles of virtual schools that augment learning and outcomes at all levels. The learning institutions stand to gain if these principles are incorporated in the course design and instructional methodology.

\section{A. Restraint and Self Discipline}

Restraint and Self-discipline are the success criteria of any online lesson. Students have to be attentive and participate in the lesson by constantly interacting with the teacher and peers. There are chances that the students may go astray as there in none watching or reprimanding them. Therefore, it becomes necessary for schools to teach them the life skills of discipline, restrain and managing oneself while indulging with technology. The resource may become purposeless if not used meaningfully and carefully.

\section{B. Online interaction for that Social connection}

School is a social institution, tens of students, teachers, support staff, admin staff, its crowded. There is that unseen connect with every staff member. The cumulative social energy of the classroom drives learning. Students learn from their peers, their class monitors, their seniors and juniors too, not in a typical formal setting but in an informal way. Lively discussions, group presentations, brainstorming enriches learning. This dynamism vanishes in an online class. The biggest obstacle between the teacher and the students is the screen. Although, they can see each other, physical interaction for learning is not experienced in a virtual media, which is the main stay of developing human values and camaraderie. This weird feeling is enough to drive the sensitive students into boredom and disconnect.

Hence, teaching has to ensure that there is constant peer interaction and activities throughout the lesson. There has to be liveliness in every single lesson delivery. Socialization and collaboration has to become fundamental part of every instructional plan. Later, students can work outside the lessons, talk to each other and complete their assignments collaboratively.

\section{Student teacher interaction}

Conversations are important for evolution. Interactions before, after and during lesson ensures that students are attentive and are a part of the teaching learning process. Without interaction, the lesson will emerge as a teacherdominated module which gives limited scope to measure and assess learning. Hence, meticulous planning is required to prepare content for online education.

\section{Effective Time Management}

Since online learning offers to students the advantage of learning at their own pace, the sessions have to be designed and delivered with sufficient time gap and planning to make sure students assimilate the course material well before they move to the next lesson. But at the same time, they have to take care that "learning at one's pace" does not motivate students to procrastinate and result in poor time management for both teachers and students. Based on the learning styles, learning strategies used by teachers should result in completion of the course within the stipulated time.

\section{The challenges of Digital Learning creating the social divide}

Digital learning while revolutionizing the opportunities of learning and career making in education, what may go wrong? Often, the Digital learning, due to multiple inbuilt challenges, becomes a cause of creation a social divide between rural and urban societies and the same is a challenge for the focus of Digital India too.

\section{A. The Invisible Technological Difficulties}

This is always taken for granted. Slow internet, limited data, poor connection issues are the known enemies of technology, which we all deal with in our day-to-day lives. These hiccups in the middle of a class or presentation can spin around the interest among learners. It is a fact that in 
the developing economies, not every household has a device to access lessons online. With several such issues, warranting social equity in accessing quality education may emerge as the biggest challenge for these economies.

Majority rural netizens depend on their smartphone or a tablet for their online activity. Accessing and attending online classes on a smart phone and emerging as smart learners is a distant goal. Well, it is not possible. Probability of parents leaving their mobile phones with children to access classes and go to their work is quite low. In such instances, the divide between learners who can access online content and those who cannot, will increase and in the long run, this gap will lead to social distinction and exploitation of the technologically poor citizens.

In addition, the dynamic nature of the industry where updates are a regular feature can cause hindrance in seamless transmission of lessons. Schools also have to earmark a budget for this additional facility. Students who use the mobile phones of their parents for accessing online lessons will miss instruction if the school's software is not optimized for mobile devices. Moreover, not everything that is online is safe for young learners. No school can assure the stakeholders that technology is totally child friendly and safe. The dependence of quality education on technology is a rare occurrence particularly in the absence of an effective and well-equipped IT team.

\section{B. Quality of teaching}

Do we have teachers who are tech savvy to handle online lessons effectively? The answer is no. It is hilarious to note that suddenly all educational institutions and educators recommend online education when they are not armed enough. Thousands of schools across the continents still practice traditional teaching. Therefore, it is suicidal to even attempt technology based teaching without planning and preparation. Transition from offline to online mode is not a downhill task especially when majority of educators still practice and believe in the old school of thought and for whom technology is a disdain for several reasons. Schools still do not have the right tools to practice technology-based approach. If schools fail to understand that online teaching is a different ball game, then they should be prepared to accept compromised standards and outcomes. In addition, several educators who are resistant to change can be a big challenge for schools.

\section{Quality of the course material}

Successful delivery of the lesson depends on the quality of the content. Content modification is essential and has to be attempted based on instructional plan and academic calendar. Activities, lesson objectives and assessment techniques will definitely vary in online lessons. It is always recommended that schools choose and develop their own content for their students rather than dive in the ocean of content available online. Even if the content is picked from online sources, it has to be trimmed based on students' needs and capacities.

\section{Social Divide}

India is a huge country with the majority population residing in villages. The rural population has its own share of difficulties when it comes to technology-based education. Rural students will always be at a disadvantage when it comes to implementing and incorporating novel technologies that require both students and parents to stay put in front of a smart phone or a desktop. There are several lakhs families in India that cannot boast of a decent desktop for their children. In such scenarios, where mobile phone is the only technical gadget available in a lower middle class family, children cannot access or learn anything that is telecasted on these devices. Parents cannot afford to leave their mobile phones with children and step out to their work destinations. This is not practical. Such issues are enough to create a huge divide in the society, among the rural and the urban learners. This digital divide will later affect every aspect of the human life. For example- we will have the technologically aware and smart students competing and contesting with students who are still naïve and not ready for the highly ambitious job market.

\section{Conclusion}

In the present situation, virtual learning is the safest option for ensuring learning continuum although it comes with its share of advantages and disadvantages as discussed above. There is no second opinion on saying that Change is the only constant. Its time learning institutions think about alternative methods to ensure that their children do not lose learning opportunities. While it is true that online education cannot replace classroom education in any era, currently, it is the only way to ensure continuity and coherence of the learning process. The effectiveness and productivity of the instruction will entirely be the schools' and educators' prerogative. Technological advancements cannot be a competition to any lesson taught by a great teacher with minimum frills but optimum student engagement and involvement. 


\section{REFERENCES}

1. Amunga, H. (2019). SHORTFALL OF CURRENT GLOBAL EDUCATION SYSTEMS. IARS'

International Research Journal, 9(2). Retrieved from

https://researth.iars.info/index.php/curie/article/vie w/101

2. Goel, N. (2019). DON'T KILL INNOVATION: MOVING TO MODERN EDUCATION. IARS' International Research Journal, 9(2). Retrieved from

https://researth.iars.info/index.php/curie/article/vie w/102

3. Jagathkar, A. (2016). Can Parental Involvement in Schools Improve the Quality of Citizenry?. IARS' International Research Journal, 6(1). Retrieved from

https://researth.iars.info/index.php/curie/article/vie w/56

4. Jagathkar, A. (2016). Draft National Education Policy 2016: Will it help in achieving education outcomes?. IARS' International Research Journal, 6(2). Retrieved from https://researth.iars.info/index.php/curie/article/vie w/60

5. Jagathkar, A. (2019). BUILDING INDIA, A COUNTRY OF INNOVATIONS. IARS'
International Research Journal, 9(1). Retrieved from

https://researth.iars.info/index.php/curie/article/vie w/99

6. Jain, D. (2019). DON'T KILL INNOVATION: CONCEPT TOWARDS A NEW ACADEMIC WORLD. IARS' International Research Journal, 9(1). Retrieved from https://researth.iars.info/index.php/curie/article/vie w/98

7. Mohammed, A. D. (2019). CHANGING EDUCATION PARADIGM: THE GLOBAL EYE LOOK. IARS' International Research Journal, 9(1). Retrieved from https://researth.iars.info/index.php/curie/article/vie w/97

8. Rodriguez, L. F. (2015). Practical Guidelines for the Practice of Knowledge Management in Higher Education. IARS' International Research Journal, 5(2). Retrieved from https://researth.iars.info/index.php/curie/article/vie w/51 